\title{
Self Efficacy Ibu dalam Pemberian Makanan pada Balita BGM (Bawah Garis Merah) di Puskesmas Mayangan Kecamatan Jogoroto Jombang
}

\author{
Mamik Ratnawati $^{*}$, Ririn Probowati², Monika Sawitri Prihatini ${ }^{3}$, Pawiono $^{4}$, Pujiani $^{5}$ \\ 1,2,3,4, STIKES Pemkab Jombang, Indonesia \\ ${ }^{5}$ Universitas Pesantren Tinggi Darul 'Ulum Jombang, Indonesia \\ mamik.perawat@gmail.com
}

\begin{abstract}
ABSTRAK
Masa balita merupakan usia penting untuk tumbuh kembang secara fisik. Pertumbuhan anak balita sangat pesat sehingga memerlukan asupan zat gizi yang sesuai dengan kebutuhan balita. Salah satu masalah gizi pada balita yang dapat dilihat dari kartu menuju sehat (KMS) adalah balita BGM (Bawah Garis Merah). Balita dengan berat badan BGM menjadi indikator awal bahwa balita mengalami gangguan masalah gizi.

Tujuan dari kegiatan ini adalah untuk mengaplikasikan penggunaan modul hasil penelitian tentang Health Promotion model terhadap self efficacy Ibu tentang pemberian nutrisi pada balita BGM (Bawah Garis Merah) Di Puskesmas Mayangan Jogoroto Jombang.

Kegiatan pengabdian masyarakat dengan Self Efficacy Ibu dalam pemberian Makanan pada Balita BGM (Bawah Garis Merah) di Puskesmas Mayangan Kecamatan Jogoroto Jombang berjalan dengan baik, ibu balita yang hadir sejumlah 25 orang ibu beserta balitanya. Ibu balita antusias dalam mendengarkan dan terdapat umpan balik dengan memberikan pertanyaan kepada pelaksana kegiatan untuk pembahasan yang belum dimengerti. Ibu balita dapat menyajikan dan membuat kreasi menu makanan untuk balita dengan BGM serta mengetahui dampak dari komplikasi masalah gizi yang ditimbulkan.

Bagi para ibu balita diharapkan mempunyai self efficacy yang baik dalam pemberian makan balita agar bisa mengatasi masalah gizi pada balitanya.
\end{abstract}

Kata Kunci: Self Efficacy Ibu, pemberian Makanan, Balita BGM

\section{PENDAHULUAN}

Masa balita merupakan usia penting untuk tumbuh kembang secara fisik. Pertumbuhan anak balita sangat pesat sehingga memerlukan asupan zat gizi yang sesuai dengan kebutuhan balita. Ukuran keberhasilan dalam pemenuhan nutrisi adalah status gizi yang diindikasikan oleh tinggi badan dan berat badan. Status gizi baik bila jumlah asupan zat gizi sesuai dengan yang dibutuhkan, sedangkan status gizi tidak seimbang dapat diprestasikan dalam bentuk gizi kurang dari yang dibutuhkan. Salah satu masalah gizi pada 
balita yang dapat dilihat dari kartu menuju sehat (KMS) adalah balita BGM (Bawah Garis Merah).

Balita dengan berat badan BGM menjadi indikator awal bahwa balita mengalami gangguan masalah gizi. Kriteria Balita BGM yakni penimbangan berat badan berdasarkan umur, jika hasil berat badan berada diwarna merah pada kartu menuju sehat (KMS) maka disebut BGM (Febry,2016). Faktor yang mempengaruhi balita BGM adalah penyakit atau cacat bawan, pendidikan orang tua, pendapatan orang tua, pengetahuan orang tua/ keluarga, dan ketidaktepatan perilaku orang tua dalam memberikan makanan bergizi pada balita (Erly Handayani, 2014).

Pertumbuhan dan perkembangan balita yang optimal mulai dari pasca kelahiran meliputi pemberian ASI eklusif dan dilanjutkan dengan pemberian ASI sampai umur 2 tahun, pemberian makanan tambahan( PMT) setelah umur 6 bulan, stimulasi pertumbuhan dan perkembangan sesuai dengan umur bayi yang dilakukan oleh ibu dan ayah. Dalam pengasuhan pemberian stimulasi pertumbuhan dan perkembangan menuntut peran seorang ibu sebagai penentu pola asuh bayi (Ui, 2013).

Bawah Garis Merah (BGM) manifestasi dari kurang asupan protein dan energi, dalam makanan sehari-hari yang tidak memenuhi angka kecukupan gizi (AKG), dan juga disertai adanya kekurangan dari beberapa nutrisi lain. Untuk menanggulangi masalah balita BGM adalah menyelenggarakan program pemerintah berupa pemberian makanan tambahan (PMT) dan cara terbaik untuk menekan angka kejadian BGM pada balita adalah dengan memberikan informasi (Hadiriesandi, 2016). Diwilayah Kabupaten Jombang dari tahun 2017 sampai tahun 2018 angka kejadian BGM naik. Pada tahun 2017 jumlah balita 39.528 balita dengan BGM sejumlah 472(0,6\%). Sedangkan balita dengan BGM tahun 2018 di Kabupaten Jombang sejumlah 511 Balita (Seksi Gizi Dinas Kesehatan Kabupaten Jombang, 2018).

Pengetahuan ibu sangat dibutuhkan dalam peningkatan self efficacy pemberian makanan pada Balita BGM. Untuk meningkatkan pengetahuan ibu, salah satu nya dapat dilakukan dengan pemberian promosi kesehatan yang pada akhirnya dapat meningkatkan self efficacy Ibu dalam ketepatan pemberian nutrisi pada balita bawah garis merah (BGM) (Dewi, 2011). Keberhasilan dalam penanganan balita dengan gizi kurang dan buruk factor utama adalah pada ibu, yang berawal dari seorang ibu melahirkan dalam pemberian ASI eksklusif pada bayinya dimana ASI merupakan support utama dalam tubuh bayi sebagai penunjang dalam pertumbuhan bayi selanjutnya. Salah satu faktor yang menentukan keberhasilan pemberian Air Susu Ibu (ASI) adalah kondisi ibu berupa keyakinan ibu untuk memberikan ASI (Rochana, Cilacap, Adipala, \& Belakang, 2019).

\section{METODOLOGI}

Kegiatan utama ini adalah mengaplikasikan penggunaan modul hasil penelitian tentang Health Promotion model terhadap self efficacy Ibu tentang pemberian nutrisi pada balita BGM (Bawah Garis Merah) Di Puskesmas Mayangan Jogoroto Jombang.

Adapun kegiatan pengabdian masyarakat tahapan sebagai berikut:

Tahap Persiapan:

1) Melakukan persiapan mulai dari ijin utuk melakukan pengabdian masyarakat baik dari LPPM STIKES Pemkab Jombang, Dinas Kesehatan Kabupaten Jombang, baik dari pihak pihak yang terkait seprti Kecamatan Jogoroto Puskesmas Mayangan, Penanggung Jawab Gizi Puskesmas Mayangan Persiapan 
Pelaksana melakukan persiapan di STIKES PEMKAB Jombang yang terdiri dari

a. Menyiapakan materi untuk pendidikan kesehatan/ penyuluhan

b. Konsumsi untuk peserta penyuluhan

c. Souvenir untuk peserta penyuluhan

d. Sertifikat, berita acara dan surat telah selesai melakukan pengabdian masyarakat dengan tim LPPM

Tahap Pelaksanaan:

1) Peserta mengisi daftar hadir yang telah di sediakan oleh Unit P2M Stikes Pemkab Jombang

2) Sebelum diberikan pendidikan kesehatan tentang pemberian makanan tambahan pada Balita BGM ibu di beri kuesioner tentang self efficacy dan Balita di timbang mengisi daftar hadir yang disediakan oleh pelaksana PENMAS

3) Peserta diberikan pendidikan kesehatan dengan menggunakan sebuah modul dan demontrasi cara memasak makanan. Modul dapat dibawa pulang cara pemberian makanan tambahan pada Balita BGM dan menggunakan oudio visul dalam pemberian materi

Tahap Evaluasi:

Setelah dilakukan evaluasi di harapkan peserta memahami pentingnya pemberian makanan bagi balita BGM

\section{HASIL DAN PEMBAHASAN}

Kegiatan pengabdian masyarakat dengan self efficacy Ibu dalam pemberian Makanan pada Balita BGM (Bawah Garis Merah) di Puskesmas Mayangan Kecamatan Jogoroto Kabupaten Jombang berjalan dengan baik, Kegiatan pengabdian masyarakat ini dihadiri oleh seluruh balita dengan BGM yang ada di wilayah kerja Puskesmas Jogoroto Kecamatan Jogoroto Kabupaten Jombang sejumlah 25 balita yang didampingi oleh ibunya. Kegiatan ini juga dihadiri oleh Kepala Puskesmas Jogoroto dan seksi gizi Puskesmas Jogoroto. Tujuan dari kegiatan pengabdian masyarakat ini diantaranya: 1) Melaksanakan Pengabdian Masyarakat dalam rangka aplikasi penggunaan modul tentang Health Promotion model terhadap self efficacy Ibu tentang pemberian nutrisi pada balita BGM (Bawah Garis Merah) Di Puskesmas Mayangan Jogoroto Jombang, 2) Melakukan Pendidikan kesehatan dan demonstrasi: Cara meningkatan self efficacy ibu dlaam pemberian makanan pada balita BGM (modul), Demonstrasi pembuatan PMT bagi balita BGM, 3) Memberikan pendidikan kesehatan tentang pentingnya makanan bagi Balita BGM, 4) Mengevaluasi Penyuluhan Pemberian Makanan Tambahan Balita BGM.

Manfaat yang dapat diperoleh dari kegiatan ini adalah agar ibu mempunyai self efficacy dalam melakukan pemberian makan Balita BGM agar balita dapat tumbuh dan berkembangan secara optimal.

Self efficacy dalam kegiatan pengabdian masyarakat ini adalah self efficacy ibu dalam pemberian makanan oleh ibu. Self efficacy diri ibu yang kurang dalam pemberian makan tentunya berkaitan dengan pola asuh makan anak meliputi prinsip pemberian gizi seimbang pada balita, pola pemberian makan balita, bentuk makanan balita dan frekuensi dan jumlah makanan balita yang tepat (Ardiani, 2019). Apabila informasi yang didapat bahwa seseorang mempunyai kemampuan tinggi dapat menambah keyakinan diri seseorang, mereka akan mengerjakan suatu tugas dengan sebaik mungkin. Namun apabila informasi kemampuannya rendah maka akan menurunkan self efficacy (Muaningsih, 2013). 


\section{KESIMPULAN}

Dengan adanya pengabdian masyarakat ini diharapkan ibu balita mempunyai self efficacy yang baik dalam pemberian makan balita agar bisa mengatasi masalah gizi pada balitanya dan menekan angka kejadian masalah gizi pada balita.

\section{DAFTAR PUSTAKA}

Ardiani, N. D. (2019). Hubungan Efikasi Diri Pemberian Makan Oleh Ibu dengan Status Gizi Balita di Plesungan Karanganyar

Dewi, N. (2011). Skripsi Faktor Dominan Karakateristik Ibu yang Berhubungan dengan Pertumbuhan dan Perkembangan Balita Usia 2 - 5 Tahun di Wilayah Kerja Puskesmas Naggalo Kota Padang, Universitas Andalas.

Erly Handayani. (2014). Pengaruh Pengetahuan Ibu dan Pendapatan Orang tua terhadap Pola Makan Anak Balita Umur 6 Bulan - 5 Tahun di Dusun 1 Desa Palumbungan Kecamatan Kecamatan Bobot Sari Kabupaten Purbalingga.

Febry, F. (2016). Determinan Kejadian Anak Balita, 7, 48-63.

Hadiriesandi, M. (2016). Evaluasi Program Pemberian Makanana

Indonesia, U., Keperawatan, F. I., Studi, P., Ilmu, M., \& Maternitas, P. K. (2013). Studi Komparasi Antara Breastfeeding Self - Studi Komparasi Antara Breastfeeding

Rochana, S., Cilacap, A. S., Adipala, P., \& Belakang, L. (2019). Siti Rochana 1 Dosen, Diploma III Keperawatan, Akper Serulingmas Cilacap Email Penulis Korespondensi (, 2(1), 7-9.

Ui, F. I. K. (2013). Peningkatan Perkembangan.., Slametiningsih, FIK UI, 2013. 